\title{
Manfaat Alga Merah(Rhodopyta) sebagai Sumber Obat dari Bahan Alam
}

\author{
Larasati Amaranggana, Nasrul Wathoni \\ Fakultas Farmasi Universitas Padjadjaran, Sumedang, Jawa Barat, Indonesia
}

\section{Abstrak :}

Indonesia merupakan negara yang kaya akan sumber keanekaragaman hayati dan memiliki kekayaan spesies laut tertinggi. Sekitar $45 \%$ spesies rumput laut dunia ada di Indonesia. Dikutip dari laporan ekspedisi Siboga, terdapat sekitar 782 spesies rumput laut di Indonesia dengan 196 spesies alga hijau, 134 spesies alga coklat, dan 452 alga merah. Sayangnya, meskipun terdapat banyak jenis rumput laut yang ditemukan diperairan Indonesia, baru sedikit jenis rumput laut yang diketahui memiliki nilai ekonomi tinggi. Padahal menurut FAO, rumput laut merupakan produk yang bisa dikembangkan menjadi makanan, kosmetika, farmasetika, bioetanol, pakan ternak, pakan ikan, aquakultur, dan penanganan limbah air. Rumput laut mengandung berbagai metabolit yang bermanfaat bagi manusia. Dibandingkan dengan rumput laut hijau dan coklat, rumput laut merah (Rhodopyta) merupakan jenis rumput laut yang paling banyak mengandung senyawa metabolit primer dan sekunder. Rumput laut merah dikenal sebagai penghasil phycocolloids seperti agarose, agar, karagenan, dan metabolit sekunder penting lainnya. Review artikel ini bertujuan untuk memaparkan aktivitas-aktivitas biologi yang dimiliki alga merah sebagai bahan referensi berbagai bidang pemanfaatan alga

Keyword: Rumput laut, Alga, Rhodophyta

\section{Pendahuluan}

Rumput laut merupakan sumber metabolit sekunder yang sangat potensial untuk dikembangkan menjadi berbagai bahan baku farmasi. Senyawa-senyawa kimia yang terkandung dalam rumput laut diantaranya adalah polisakarida, lipid, protein, alkaloid, dan senyawa fenolik (de Almeida et al., 2011).

Rumput laut (alga) merupakan makroalga yang umumnya memiliki thallus dan pigmen fotosintetik untuk memproduksi makanan dan oksigen dari karbondioksida dan air. Rumput laut diklasifikasikan berdasarkan wama pigmennya. Rumput laut hijau (Chlorophyta) mengandung klorofil sebagai pigmen utamanya. Alga coklat (Phaeophyta) mengandung pigmen fucoxantin. Dan alga merah (Rhodophyta) mengandung pigmen-pigmen seperti phycoerythrine, phycocyanin, phycobilins, klorofil a, $\beta$-karoten, dan xanthophyl (Kasanah etal., 2015).

Rumput laut merupakan sumber yang menjanjikan untuk berbagai macam pengembangan. Umumnya, rumput laut digunakan sebagai makanan, pupuk, dan juga obat-obatan. 
Rumput laut mengandung serat, karbohidrat, lemak yang rendah, mineral, vitamin, dan asamasam amino sehingga cocok dijadikan bahan pangan dan bermanfaat untuk kesehatan. Selain itu, kandungan metabolit primer (phycocolloid) seperti karagenan, agar, serta alginatnya dapat digunakan sebagai gelling, stabilizing, dan thickening agents pada makanan, kosmetika, dan industri farmasi. Metabolit lainnya yaitu polysulfated polisaccharides seperti laminaran, rhamnan sulfate, galaktosil gliserol, dan fukoidan yang memiliki aktivitas sebagai antioksidan, antialergik, anti-HIV, antikanker, dan antikoagulan. Penelitian lain juga melaporkan bahwa rumput laut memiliki aktivitas antibakteri dan antiinflamasi (Jiao et al., 2011;Pomin et al., 2008; Ngo et al., 2013; Lee et al., 2013; dan Maftuch et al., 2016).

Berbagai macam metabolit sekunder yang disintesis dari rumput laut diantaranya adalah karotenoid, polifenol, terpenoid, xantofil, klorofil, vitamin, alkaloid, asam lemak jenuh dan asam lemak tak jenuh (Takaichi, 2011; Guven et al., 2010; dan Maschek et al., 2008).

\section{Alga merah (rhodopyta)}

Alga merah merupakan jenis alga yang lebih banyak memiliki aktivitas biologi dibandingkan dengan jenis alga lainnya. Senyawa-senyawa kimia yang ada pada alga merah didominasi dari famili Rhodomelaceace. Alga merah merupakan sumber pembentuk utama halogenated compunds seperti laurenterol (1), halomon (2), callicladol (3) dan senyawa lainnya seperti pada gambar 1 (Kladi et al., 2003; Cabrita et al., 2010).

Halogenated compunds memiliki beragam aktivitas seperti antibakteri, antifungi, antiinflamasi, iktiotoksik, sitotoksik, dan insektisidal. Selain itu, alga merah juga mengandung terpenoid, polieter, asetogenin, beberapa asam amino, sikimat, serta derivat asam nukleat dan asetat (Maschek, et al., 2008; Kladi et al., 2003; Cabrita et al., 2018; Pedersen et al., 1974; dan Ayyad et al., 2011).

\section{Berbagai Aktivitas Biologi Alga Merah}

Terdapat beberapa jenis alga merah yang diketahui memiliki aktivitas antibakteri. Senyawa antibakteri ini diisolasi dari alga merah seperti Laurencia spp., Gracillaria spp., Acanthophora spp., dan spesies alga merah lainnya (Kasanah et al., 2015).

\section{Laurencia spp}

Alga merah genus Laurencia (Rhodomelaceace, Ceramiales) umumnya ditemukan pada perairan tropis maupun subtropis. Berbagai varian senyawa metabolit sekunder seperti $\mathrm{C}_{15^{-}}$ acetogenin, $\mathrm{C}_{15^{-}}, \mathrm{C}_{20^{-}}$, dan $\mathrm{C}_{30^{-}}$-terpenoid (Kladi et al., 2008).

Lima senyawa antibakteri yang diisolasi dari spesies Laurencia sp. diketahui memiliki aktivitas terhadap bakteri Staphylococcus aureus, Staphylococcus sp., Streptococcus pyogenes, Salmonella sp., dan Vibrio cholerae. Senyawa-senyawa tersebutialah 10-acetoxyangasiol, aplysidiol, cupalaurenol, 1-methyl-2,3,5-tribromoindole, dan chamigrane epoxide. Dari hasil penelitian, nilai MIC yang rendah dimiliki oleh 10-acetoxyangasiol terhadap V. cholerae yaitu 100 $\mu \mathrm{g} / \mathrm{mL}$ (Vairappan et al., 2010). 


\section{Acanthophora spp.}

Genus Acanthophora merupakan alga merah yang paling banyak ditemukan di perairan tropis maupun subtropis. Akan tetapi penelitian tentang spesies ini masih sedikit. Beberapa sterol yang diisolasi dari Acanthophora spicifera diantaranya adalah 6-hydroxycholest-4-ene-3-one, cholest4-ene-3,6-dione, cholest-5-ene-3 $\beta$-ol, 5a-cholestane-3,6-dione, dan senyawa lainnya. Penelitian menujukkan bahwa beberapa senyawa sterol menunjukkan adanya aktivitas antibakteri (Wahidulla etal., 1998; Lang et al., 2007).

\section{Gracilaria spp.}

Genus Gracilaria memiliki lebih dari 300 spesies. Genus ini berperan penting pada industri bioteknologi karena sebagai sumber agar dan agarose yang banyak digunakan pada industri makanan, farmasetika, dan kosmetik. Gracilaria spp memiliki metabolit bioaktif yang berfungsi sebagai antibakteri seperti steroid, terpenoid, dan derivat asam eicosanoid. Berdasarkan penelitian yang dilakukan oleh Maftuch et al (2016), Gracilaria Verrucosa mengandung senyawa alkaloid, flavonoid, tanin, dan fenol. Selain sebagai antibakteri, G. Verrucosa juga memiliki aktivitas sebagai antioksidan. Senyawa fenol yang ada pada jenis alga ini terbukti memiliki khasiat sebagai antibakteri, antiinflamasi, antivirus, dan antikarsinogenik (Widowati et al., 2014).

\section{Callophycus serratus}

Callophycus serratus merupakan alga merah yang banyak ditemukan di perairan tropis dan subtropis terutama di wilayah Asia Tenggara, Pasifik, dan Afrika. Beberapa senyawa yang berhasil diisolasi dari jenis ini memiliki aktivitas sebagai antibakteri, antifungi, antikanker, antimalaria, dan antitubekular (Lin et al., 2019; Kubanek et al., 2006; Kubanek et al., 2005; dan Lane et al., 2007).

\section{Rhodomella spp.}

Rhodomella confervoides mengandung senyawa bromofenol yang memiliki aktivitas sebagai sitotoksik dan antibakteri. Dari beberapa senyawa yang berhasil diisolasi, senyawa bis (2,3-dibromo-4,5dihydroxybenzyl) eter adalah senyawa yang paling kuat aktivitas antibakterinya dengan nilai MIC kurang dari $70 \mu \mathrm{g} / \mathrm{mL}$ (Xu et al., 2003).

\section{Kesimpulan}

Senyawa kimia yang terdapat pada alga merah memiliki berbagai macam khasiat dan aktivitas seperti antibakteri, antioksidan, antiinflamasi, antivirus, dan antikarsinogenik. Alga merah menjadi sumber penting yang dapat dikembangkan menjadi sumber bahan obat yang berasal dari alam.

\section{Daftar Pustaka}

Ayyad, S.E., Al-Footy, K.O., Alarif, W.M., Sobahi, T.R., Bassaif, S.A., Makki, M.S., Asiri, A.M., Al Halwani, A.Y., Badria, A.F., and Badria, F.A., 2011, Chem. Pharm. Bull., 59(10), 1294-1298

Cabrita, M.T., Vale, C., and Rauter, A.P., 2010, Mar. Drugs, 8(8), 2301-2317.

de Almeida, C.L.F., Falcão, H.d.F., Lima, G.R.d.M., Montenegro, C.d.A., Lira, N.S., de Athayde-Filho, P.F., Rodrigues, L.C., de Souza, M.d.F.V., Barbosa-Filho, J.M., and Batista, L.M., 2011, Int. J. Mol. Sci., 12(7), 4550-4573.

Güven, K.C., Percot, A., and Sezik, E., 2010, Mar. Drugs, 8(2), 269-284. 
Jiao, G., Yu, G., Zhang, J., and Ewart, H.S., 2011, Mar. Drugs, 9(2), 196-223.

Kasanah, Noer., Triyanto, Drajad S.S., Windi Amelia, dan Alim Isnansetyo, 2015, Indones. J. Chem., 2015, 15 (2), $201-209$.

Kladi, M., Vagias, C., and Roussis, V., 2003, Phytochem. Rev., 3(3), 337-366.

Kladi, M., Vagias, C., Stavri, M., M. Rahman, M.M., Gibbons, S., and Roussisa, V., 2008, Phytochem. Lett., $1(1), 31-36$

Kubanek, J., Prusak, A.C., Snell, T.W., Giese, R.A., Fairchild, C.R., Aalbersberg, W., and Hay, M.E., 2006, J. Nat. Prod., 69(5), 731-735.

Kubanek, J., Prusak, A.C., Snell, T.W., Giese, R.A., Hardcastle, K.I., Fairchild, C.R., Aalbersberg, W., Raventos-Suarez, C., Hay, M.E., 2005, Org. Lett., 7(23), 5261-5264.

Lang, K.L., Palermo, J.A., Falkenberg, M., and Schenkel, E.P., 2007, Biochem. Syst. Ecol., 35,805-808.

Lee, J-C., Hou, M-F., Huang, H-W., Chang, F-R., Yeh, C-C., Tang, J-Y., and Chang, H-W., Cancer Cell Int., 13, 1-7.

Lin, A.S., Stout, E.P., Prudhomme, J., Le Roch, K., Fairchild, C.R., Franzblau, S.G., Aalbersberg, W., Hay, M.E., and Kubanek, J., 2010, J. Nat. Prod., 73(2), 275-278.

Maschek, J.A., and Baker, B.J., 2008, "The Chemistry of Algal Secondary Metabolism" in Algal Chemical Ecology, Amsler, C.D., Springer-Verlag Berlin Heidelberg, Germany, 1-24.

Maftuch, Isma Kurniawati, Awaludin Adam, dan I'ah Zamzami, 2016, Egyptian Journal of Aquatic Research (2016)42, 405-410

Ngo, D.H., and Kim, S.K., 2013, Int. J. Biol. Macromol., 62, 70-75.

Pedersén, M., Saenger, P., and Fries, L., 1974, Phytochemistry, 13(10), 2273-2279.

Pomin, V.H., and Maurão, P.A., 2008, Glycobiology, 18(12), 1016-1027.

Takaichi, S., 2011, Mar. Drugs, 9(6), 1101-1118. 13.

Vairappan, C.S., Ishii, T., Lee, T.K., Suzuki, M., and Zhaoqi, Z., 2010, Mar. Drugs, 8(6), 1743-1749.

Wahidulla, S., D'Souza, L., and Govenker, M., 1998, Phytochemistry, 48(7), 1203-1206.

Widiowati, Ita., Daphne Lubac, Maya Puspita, dan Nathalie Bourgougnon, 2014, International Journal of Latest Research in Science and Technology ISSN (Online):2278-5299 Volume 3, Issue 3: Page No. 179-185. Xu, N., Fan, X., Yan, X., Li, X., Niu, R., and Tseng, C.K., 2003, Phytochemistry, 62(8), 1221-1224. 